UDC 378.811 .111

\title{
THE ROLE OF AUTHENTIC VIDEOS IN TEACHING ENGLISH AT TECHNICAL UNIVERSITIES
}

\author{
M. V. Shevchenko \\ Kyiv, National Technical University of Ukraine "Kyiv Polytechnic Institute" \\ marianashevchenko@ukr.net
}

\begin{abstract}
The article deals with the role of authentic videos in teaching English at technical universities. The positive aspects of audiovisual aids' influence, concerning the engagement of both (left and right) hemispheres of the human brain, are reviewed. The main attention of the article is focused on the benefits and goals of using authentic video materials for language learning and teaching, as well as the advantages of using videos at the English language lessons at technical universities. The meaning of the notion "classroom management" is defined. The proposed paper also presents conditions for the good foreign language learning environment in the classroom. The most appropriate sources from which to select videos or their fragments for a technical university's English lessons are provided. The criteria of video selection, which must be taken into account while preparing for the English teaching-learning process, can be found in the article. The basic ways of how to use videos at the English for Specific Purposes lessons in non-linguistic higher educational institutions are given. In order to reach the lesson's objectives, it is necessary to create a sequence of interrelating activities at different stages of the lesson, which are opening, sequencing, and closing. Recommendations for work at each of the above-mentioned steps, using videos, are presented.
\end{abstract}

Key words: videos, audiovisual materials, authentic, the English language, technical universities, English for Specific Purposes.

Introduction. The continuous technological progress influences the teaching process significantly every year. It is no longer possible to teach English at universities only with the help of course-books and hand-outs. At technical universities this issue is the most acute, while their students deal with state-of-the-art technologies. Therefore, application of up-to-date authentic video materials into the English language teaching is what the lecturers should aim at nowadays. This makes the research presented in the article of current importance.

Aim and tasks. The goal of this paper is to describe the features and the role of authentic videos in teaching English at technical universities. The tasks of the research are: to determine the influence of audiovisual materials on students and their work at a foreign language lesson; to list benefits and basic ways of using authentic videos for the English language learning and teaching, specifically at technical universities; to enumerate criteria of authentic videos selection and purposes of audiovisual materials application in the classroom, as well as the most appropriate sources from which to select videos; to examine the role and exploitation of authentic videos at three stages of the English lesson (opening, sequencing and closing).

Background. The issue of using authentic videos at foreign language lessons has been studied by R. A. Berk [1], J. Brophy [2], I. Cakir [3], C. Canning-Wilson [4], P. Cummins [5], J. C. Richards and D. Bohlke [8], J. Sherman [9], J. Wang and K. Hartley [10], K. Woottipong [11], and others. Nevertheless, at higher technical educational institutions the use of video materials as a crucial addition to the work productivity enhancement at the English lessons still remains an active area of pedagogical research.

Research. The key problem that technical students, who study English, face is that they often do not understand the concepts or processes, even related to their speciality, which they listen to or read about in the foreign language classroom. Mainly this happens due to the lack of visual presentation. Not every student has vivid enough imagination to relate the concept they read about in English to the one they have already studied at professional lessons conducted in their native language. This is exactly the case when the English language teachers need authentic videos, or audiovisual materials, at their lessons at technical universities. It is necessary to mention that materials are defined as authentic when they are intended for some other use besides language learning [11, p. 101]. 
There are two brain hemispheres that relate to different ways of thinking: verbal (the left) and nonverbal (the right). The former is a logical and analytical, which processes information successively, e.g. in mathematics, logic, language. The verbal hemisphere is concerned with facts, rather than theories, and is structured, precise, rational, strategic, as well as objective. The latter, nonverbal, hemisphere is, on the contrary, a creative side, being spontaneous, emotional, disorganized, empirical, empathic, biased, intuitional, and concentrating on images, colour, and melody. Audiovisual aids employ both parts of the cerebrum: the left analyses words and the discourse on the whole, subject matter, rhythm, whereas the right one processes the visual imagery, relations, and sound effects [1, p. 3].

Taking into account physical differences in the neuronal networks of brain, it is essential to familiarize students of technical specialities with a vast range of learning strategies with help of videos. They can promote verbal and visual, i.e. linguistic and spatial, learning styles [1, p. 3; 7]. According to R.A. Berk [1, p. 3], verbal / linguistic learning constitutes reading, speaking (including debating and discussing), listening, as well as writing, whereas visual / spatial learning happens during seeing, imagining, creating mental pictures, etc.

Multiple studies on the application of videos at the English lessons prove their effectiveness, and thus, many scholars recommend using this activity on an ongoing basis $[1$, p. $5 ; 2 ; 5 ; 10]$. In C. Canning-Wilson's research [4] students' preference for increased use of authentic videos at lessons is revealed, whilst other researchers state that audiovisual materials can also improve students' understanding of specific subject matters and contexts.

There are such benefits of using authentic video materials for language learning and teaching:

- giving samples of any sphere of real-life in the process of the classroom study [9, p. 1];

- helping students focus on the language skills they actually need and ignore skills they may not need for their job or studies;

- inspiring students and stimulating language learning: they are more interesting than specially prepared ones. Students will desire to watch presented videos even if their comprehension is insufficient [11, p. 203-204];

- focusing on meaning instead of forms or structures of words and expressions. Students acquire a foreign language when they activate their background knowledge of the world and its concepts, discourse, as well as the language system [11, p. 203]. I. Cakir claims that by employing videos at the English lesson "students contextualize the language they have learnt" [3, p. 71].

The best quality of any video, being a programme or a (part of) movie, is grabing the viewer's attention and evoking different emotions, so that everybody will definitely remember what he / she has watched and, at the same time, subconsciously enrich English vocabulary, consisting of lexis used on the video.

Authentic video aids can be used at the English lesson to:

- attract students' attention;

- motivate and enspire;

- provide content and information;

- illustrate a concept (new or previously presented);

- relate content to real-world applications (graphic examples of the use of studied processes or technologies);

- serve as an impetus for learning activities (especially in the collaborative form, i.e. discussion, or assessment of certain equipment functioning in a Hollywood movie, for example) [1, p. 11-13].

This team-oriented study prompts deep learning, helps to improve students' multiple skills (leadership; artistic, speaking and technical skills, etc.), and thus, increases the success of every student, which proves that there is a connection between the media and the students' intelligence $[1$, p. $14 ; 7]$.

A positive learning environment is a crucial aspect of an effective lesson. It may be created only with the help of a qualified foreign language teacher, who is an enthusiastic, good classroom manager, sets high expectations for their learners, and establishes trustful relationships with the 
students [6;8, p. 11]. The word combination "classroom management" stands for ways in which special arrangements are done in the class to set up a supportive teaching and learning environment, which is a prerequisite to a successful lesson [12]. An optimistic and supportive atmosphere in some classrooms can be felt straightaway: people, who study, are relaxed, focused, motivated, have good co-operation [8, p. 7-8].

Taking into account the fact that most universities, especially technical ones, do not possess big, if any, collections of video materials in English, relevant to students' specialities, the English teacher should find and prepare the lessons' audiovisual aids on his/her own. The researcher R.A. Berk mentions the most appropriate sources from which to select videos for a university's foreign lessons [1, p. 8]:

- Movies (or their fragments) based on cult classics, Oscar winners, as well as most recent and popular ones;

- TV-programmes, apt for the university age groups of people and their specialities;

- YouTube videos (corresponding to the students' speciality and the topic of the lesson) that are top-rated or most often viewed.

For each lesson or topic, a teacher should choose a suitable video that would be a meaningful adjuvant to the teaching-learning process. In order to do so, the following criteria of video selection must be taken into account: knowledge, etc.);

- socio-demographic characteristics of students (age, level of the English language

- the structure of a video (length, authenticity, relevance to the lesson's topic, number of characters on it);

- mental and ethical influence on the viewers;

- genre.

The advantages of using videos at the English language lessons at technical universities are the following [1, p. 2]: to grab students' attention and focus their concentration on the topic of the lesson; to generate interest in the auditorium and stimulate communication in English; to produce catchy visual images; to enhance students' imagination; to improve attitudes toward content and study; to increase understanding and memorization of studied content; to allow freedom of expression, and serve as a stimulant to teamwork in the auditorium; to embolden and galvanize students; to make study fascinating; to decrease anxiety or fear of speaking English in the class.

The prepared aids can be presented at the lesson with the help of a notebook or special equipment in the multimedia class. It is important to remember that videos viewing in the auditorium should differ from a typical passive television watching [3, p. 71]. There are numerous ways of implementing videos at the English lesson. The mentioned below are the basic ones, but others can be added if needed [1, p. 10]:

1. Select a video or a fragment of a movie / programme etc. to introduce to students a concept or process, which is to be studied;

2. Provide students with guidelines or discourse questions so that they understand what details to pay special attention to during the viewing;

3. Briefly introduce the video to emphasize the goal;

4. Play the video or the fragment;

5. (It may be possible to) stop the video at any point to highlight some moment or replay the audiovisual aid for a particular in-class activity;

6. Set a time for reflection on what was seen;

7. Organize an active learning activity to interact on certain issues or concepts in the clip;

8. Promote a further discussion in small and/or large groups concerning the watched material.

In order to reach the lesson's objectives, it is necessary to create a sequence of interrelating activities (opening, sequencing, and closing) [8, p. 9].

At the opening stage a teacher can ask questions to develop ideas related to the topic or assess the students' background knowledge of a particular process or concept, concerning their speciality; use brainstorming and debates; ask students to write a brief test, but the best way to 
attract students' attention is to show a video or a short fragment of some movie or programme related to the lesson's theme.

It is vital to bear in mind that valid lesson transitions help maintain students' attention and establish a link between the exercises. Thus, activities of the sequencing part of the lesson should be skilfully connected with the video presented in the opening part. Another audiovisual material may be added at this stage as well, which will further expand the understanding of the topic and facilitate faster achievement of the lesson's goals.

Videos may also play a vital part at the final, closing, stage. They can help sum up what the lesson attempted to accomplish; comprising the vocabulary studied at the lesson, showing it in action, and thus motivating students to continue studying English for Specific Purposes, as long as they can see that it is applied in the real, "living", language used by native speakers, who are their future colleagues in the scientific sphere they tend to become experts at.

It must be said that the use of authentic videos is becoming more and more indispensable at the English language lessons at technical universities. Audiovisual materials help not only create clearer understanding of what students are learning, but also noticeably improve their English vocabulary, getting examples of the use of the studied words and expressions in their authentic environment, i.e. in the "living" language. And what is more important, videos help to create confiding and calm atmosphere, and, as a result, establish successful collaboration of students, as well as the teacher-students relationship.

Conclusion. In this article features and the role of authentic videos in teaching English at technical universities have been discussed. Inter alia, the influence of audiovisual materials on students and their work at a foreign language lesson is determined. The main attention has been paid to the benefits and basic ways of using authentic videos for the English language learning and teaching, specifically at technical universities. Important elements of this work are the enumerated criteria of authentic videos selection, purposes of audiovisual materials application in the classroom, and the most appropriate sources from which to select videos for a university's foreign lessons. Last but not least, the role and exploitation of authentic videos at the opening, sequencing and closing stages of the English lesson have been examined. All the aforesaid information presented in this written work proves the fact that no advanced English lesson at a technical university can do without the authentic English videos.

\section{REFERENCES}

1. Berk, R. A. (2009). Multimedia Teaching with Video Clips: TV, Movies, YouTube, and mtvU in the College Classroom. International Journal of Technology in Teaching and Learning. 5 (1), 1-21.

2. Brophy, J. (Ed.). (2004). Using Video in Teacher Education. Oxford, UK: Elsevier.

3. Cakir, I. (2006). The Use of Video as an Audio-Visual Material in Foreign Language Teaching Classroom. The Turkish Online Journal of Educational Technology - TOJET. 5 (4), 67-72.

4. Canning-Wilson, C. (2000). Practical Aspects of Using Video in the Foreign Language Classroom. The Internet TESL Journal. 6(11). Retrieved from: http://iteslj.org/Articles/Canning-Video.html. Last accessed 20th April 2015.

5. Cummins, P. (1989). Video and the French Teacher. French Review. 62, 411-426.

6. Dornyei, Z. (2001). Motivational Strategies in the Language Classroom. Cambridge: Cambridge University Press.

7. Gardner, H. (2000). Can Technology Exploit Our Many Ways of Knowing? In D. T. Gordon (Ed.), The Digital Classroom: How Technology is Changing the Way We Teach and Learn (pp. 32-35). Cambridge, MA: President and Fellows of Harvard College.

8. Richards, J. C. and Bohlke, D. (2011). Creating Effective Language Lessons. Cambridge: Cambridge University Press.

9. Sherman, J. (2003). Using Authentic Video in the Language Classroom. Cambridge: Cambridge University Press.

10. Wang, J. \& Hartley, K. (2003). Video Technology as a Support for Teacher Education Reform. Journal of Technology and Teacher Education. 11 (1), 105-138.

11. Woottipong, K. (2014). Effect of Using Video Materials in the Teaching of Listening Skills for University Students. International Journal of Linguistics. 6 (4), 200-212.

12. Wright, T. (2005). Classroom Management in Language Education. Basingstoke: Palgrave Macmillan. 
М. В. Шевченко. Роль автентичних відео в навчанні англійської мови в технічних університетах.

Стаття присвячена ролі автентичних відео в навчанні англійської мови в технічних університетах. Розглядаються позитивні особливості впливу аудіовізуальних засобів, які задіюють обидві (ліву та праву) півкулі людського мозку. В статті головна увага присвячена перевагам використання автентичних відеоматеріалів для навчання й вивчення іноземної мови, а також позитивним сторонам використання відеозаписів на заняттях з англійської мови в технічних університетах. Праця містить список цілей, яких можна досягнути завдяки використанню відео на заняттях із англійської мови. Пояснюється значення поняття «управління аудиторією» (“classroom management”). В роботі, що пропонується, також розглядаються передумови для створення позитивного середовища навчання іноземної мови в університетській аудиторії. Надається перелік найбільш підходящих джерел, з яких можна вибирати ціле відео або фрагменти. У праці можна знайти критерії відбору відеозаписів, які треба враховувати під час підготовки процесу навчаннявивчення англійської мови. Оскільки більшість технічних університетів не мають обширної бази для навчання іноземної мови з використанням автентичних відеоматеріалів, викладачу необхідно самостійно шукати й готувати аудіовізуальні засоби для роботи на занятті, таким чином наприкінці наводяться основні варіанти використання відео на заняттях із технічної англійської мови в немовних вищих навчальних закладах. Для того, щоб досягти поставленої мети, необхідно створити послідовність взаємопов'язаних видів роботи на різних етапах заняття. Ними є початок, основний етап і заключна частина. Рекомендації стосовно роботи на кожному 3 них із використанням відео аналізуються в цій статті.

Ключові слова: відео, аудіовізуальні матеріали, автентичні, англійська мова, технічні університети, англійська мова для спеціальних цілей.

\section{М. В. Шевченко. Роль аутентичных видео в обучении английскому языку в технических} университетах.

Статья посвящена роли аутентичных видео в обучении английскому языку в технических университетах. Главное внимание уделяется преимуществам использования видео во время обучения иностранному языку и его изучения, особенно на занятиях в технических университетах. Также рассматриваются положительные особенности влияния аудиовизуальных средств, которые задействуют оба (левое и правое) полушария мозга человека. Работа содержит список целей, которых можно достичь, используя видеозаписи на занятиях английского языка, перечень наиболее подходящих источников целых видео или фрагментов, предпосылки создания позитивной среды обучения в университетской аудитории, а также объяснение значения такого понятия как «управление аудиторией» (“classroom management”). В статье можно найти важные критерии отбора видеозаписей и основные варианты их использования на занятиях по техническому английскому языку в неязычных высших учебных заведениях. Для того чтобы достичь поставленной цели, необходимо создать последовательность взаимосвязанных видов работы на разных этапах занятия - начальном, основном и заключительном. Рекомендации по работе на каждом из них, используя видео, анализируются в этой статье.

Ключевые слова: видео, аудиовизуальные материалы, аутентичные, английский язык, технические университеты, английский язык для специальных целей. 